\title{
Phytoprotection
}

\section{William Pollock Fraser (1867-1943) : Canadian pioneer plant pathologist-mycologist}

\section{R.H. Estey}

Volume 73, numéro 2, 1992

URI : https://id.erudit.org/iderudit/706019ar

DOI : https://doi.org/10.7202/706019ar

Aller au sommaire du numéro

\section{Éditeur(s)}

Société de protection des plantes du Québec (SPPQ)l

\section{ISSN}

0031-9511 (imprimé)

1710-1603 (numérique)

Découvrir la revue

Citer cet article

Estey, R. (1992). William Pollock Fraser (1867-1943) : Canadian pioneer plant pathologist-mycologist. Phytoprotection, 73(2), 53-59.

https://doi.org/10.7202/706019ar
Résumé de l'article

William P. Fraser est le premier phytopathologiste-mycologue originaire du Canada à être reconnu internationalement. Alors qu'il enseignait dans sa province natale, la Nouvelle-Ecosse, Fraser débuta sa carrière à titre d'amateur en collectionnant les champignons et particulièrement ceux responsables des rouilles des plantes. Il devint un spécialiste renommé des rouilles et un phytopathologiste-mycologue professionnel. Il enseigna d'abord la mycologie et la phytopathologie, à l'Université McGill puis à l'Université de la Saskatchewan, après avoir été pour un temps chef du premier laboratoire de phytopathologie de l'Ouest canadien. Fraser fut un chercheur pionnier canadien dans la recherche sur les races physiologiques de la rouille du blé, sur la culture des rouilles hétéroïques, en pathologie forestière ainsi que dans l'étude des maladies des racines et du charbon des graminées dans l'ouest du Canada. 


\title{
William Pollock Fraser (1867-1943): Canadian pioneer plant pathologist-mycologist
}

\author{
Ralph H. Estey ${ }^{1}$
}

Received 1992-01-29; accepted 1992-07-29

William P. Fraser, the first Canadian-born plant pathologist-mycologist to be internationally recognized as such, began as an amateur collector of fungi, with emphasis on the plant rusts, while teaching school in his home province, Nova Scotia. He then became a widely acclaimed authority on the rusts and a professional plant pathologist-mycologist. He taught plant pathology and mycology, first at McGill University and then, after an interval as head of the first plant pathology laboratory in Western Canada, at the University of Saskatchewan. Fraser was a Canadian pioneer in research on physiological races of wheat rust; in the culture of heteroecious rust fungi, in forest pathology, and in the study of root and smut diseases of grasses in Western Canada.

Estey, R. H. 1992. William Pollock Fraser (1867-1943): Canadian pioneer plant pathologist-mycologist. PHYTOPROTECTION 73: 53-59.

William P. Fraser est le premier phytopathologiste-mycologue originaire du Canada à être reconnu internationalement. Alors qu'il enseignait dans sa province natale, la Nouvelle-Écosse, Fraser débuta sa carrière à titre d'amateur en collectionnant les champignons et particulièrement ceux responsables des rouilles des plantes. II devint un spécialiste renommé des rouilles et un phytopathologiste-mycologue professionnel. II enseigna d'abord la mycologie et la phytopathologie, à I'Université McGill puis à l'Université de la Saskatchewan, après avoir été pour un temps chef du premier laboratoire de phytopathologie de I'Ouest canadien. Fraser fut un chercheur pionnier canadien dans la recherche sur les races physiologiques de la rouille du blé, sur la culture des rouilles hétéroïques, en pathologie forestière ainsi que dans l'étude des maladies des racines et du charbon des graminées dans l'ouest du Canada.

The first Canadian-born plant pathologist to be internationally acclaimed as such was William Pollock Fraser, a native of French River (Merigomish), Pictou County, Nova Scotia, where he was born on a farm in 1867; one of four children of Alexander and Annabel (Pollock) Fraser. Alexander Fraser died in July 1870, leaving his wife with three small boys and a girl. William, the middle son, was only three years old.

1. Department of Plant Science, Macdonald Campus of McGill University, Sainte-Annede-Bellevue, Québec, Canada H9X 3V9.

\section{Early education}

William got his first formal education in the local school but because both of his brothers died of scarlet fever in 1887 the major burden of running the family farm soon became his responsibility. As a consequence of this, it was not until his twenty-first year, when his mother sold the farm, that Fraser was able to attend the New Glasgow High School and, later, the Pictou Academy, from which he graduated in 1896. His transfer to the Academy was fortuitous because it was there that he became interested in fungi, plant diseases and outdoor studies in general. It 


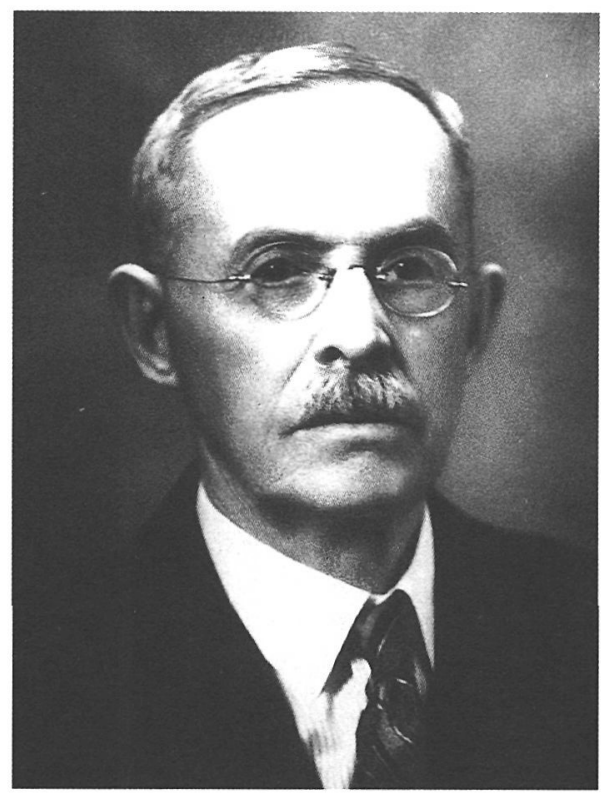

William P. Fraser

had become traditional for the science teachers there to take students on field trips, after Alexander H. MacKay (18481929), a well-known amateur mycologist, had done so many times during his principalship of 16 years.

Following his graduation, young Fraser worked for a few months and then attended the Provincial Normal School in Truro, which at that time included courses in agriculture. He thus obtained a teacher's license and an agricultural diploma in one year. Because he had to finance his own education he again had to work for awhile before enrolling in Dalhousie University in 1899. After two years he ran short of funds and left the University to become Principal of the Westville High School. In 1903 he returned to the Pictou Academy as Instructor in Natural Science. Two years later he obtained leave to attend Cornell University where he earned a B.A. degree in one year. During that year his enthusiasm for mycology and plant pathology were again stimulated; this time by Professor G.F. Atkinson, with whom he went on numerous mycological and plant disease forays (Vanterpool 1944).

Professional life in Nova Scotia

When Fraser returned to his teaching position in the Pictou Academy, he began collecting fungi in the surrounding region. Some of those fungi, collected in 1906, were sent to Alexander H. MacKay, who was then Nova Scotia's Superintendent of Education, for inclusion in his supplemental list of Nova Scotia fungi (MacKay 1908). When Fraser took his students on field trips he tended to focus their collecting efforts on fungi, and plants infected with fungi. For awhile they searched mainly for plants infected with powdery mildews. Seven of his students wrote brief reports on their collections which, together with a paper on the Erysiphaceae by Fraser, were published in the first Bulletin of the Pictou Academy of Science Association, in 1909. Incidentally, one of those seven students was Fraser's nephew, John Craigie (1887-1989), the man who, in 1927, was widely acclaimed for his discovery of the function of the pycnia of the rust fungi (Craigie 1927).

In the meantime officials at Dalhousie University had become so impressed by the accomplishments of this young man that they awarded him a B.A. degree on 25 April 1907. The University senate minute book for 24 April includes a copy of the convocation program which shows that Fraser was the only one in a special category: "Bachelor of Arts. Ad eundem gradum William Pollok Fraser, B.A. (Cornell) 1907.» Thus, his degree was an honorary one, granted for work that had been largely done elsewhere. The University records, and Fraser's marriage certificate, spell his middle name as Pollok, rather than Pollock.

It wasn't long before Fraser began to concentrate on the rust fungi, some of which he sent to Dr. J.C. Arthur, an internationally known authority of the rust fungi at Purdue University, to have his diagnoses confirmed. For example, when Fraser found the aecial stage of blueberry rust on balsam fir [Abies balsamea (L.) Mill.], in July of 1909, he sent it to Arthur who publicized the fact that this was the first such collection in North America (Arthur 1910). That correspondence with Arthur, and their exchange of specimens, continued for many years.

Fraser was a very modest, self effacing man, with a slight inferiority complex. 
Having his identification of rusts confirmed by Arthur was a stimulus, and a spur to the work that led to his becoming a renowned authority on the plant rusts. Arthur became somewhat of a role model for Fraser who from that time onward was much more of a rust specialist than a general naturalist, although he was a naturalist for the rest of his life.

One ofFraser's great accomplishments, in those early days of his career, was the production of a monograph on "The Rusts of Nova Scotia." Although read before members of the Nova Scotia Institute of Science on 23 May 1910, it was not published, with some additions, until 1913 (Fraser 1913). That monograph, embodying the results of field, cultural and microscopical studies over a period of only two years, may well be considered as the beginning of "scientific" research on the rust fungi in Canada. In it Fraser described 92 species and two forms of rusts, several of which had not been previously reported from North America, and he noted that the fungus Darluca filum (Biv.Bern. ex Fr.) Cast. was often found parasitizing the rust fungi. Fraser's early work on that monograph was recognized by Dalhousie University, which, according to the University Calendar for 1911, conferred on him the degree of Master of Arts "by Thesis in Biology," on 28 April 1910.

Fraser did not simply collect rust fungi, he cultured many of them, especially those from infected trees. In doing this he was, in a very real sense, a Canadian pioneer forest pathologist. Those early experiments on the culture of heteroecious rust fungi were carried out in the laboratory of Pictou Academy, where he was the first to work out the life histories of Melampsora arctica Rostr., Melampsoropsis pyrolae (DC) Arthur, Necium farlowii Arthur, Pucciniastrum minimum (Schw.) Arthur, and Uromyces spartinae Farl. (Fraser 1912a).

\section{Professional life in Québec}

In 1911 McGill University invited Fraser to accept a lectureship in biology in its Faculty of Agriculture at Macdonald College, Sainte-Anne-de-Bellevue, Québec. Although he was reluctant to leave the security of the Academy, and his many friends and relatives in the Pictou area, Fraser accepted the position and went to Macdonald College in January 1912. He did this knowing that Miss Alice Adele MacRae would become his bride and join him there later in the year. They were married on 18 July 1912, in Durham, Nova Scotia, the bride's home town (Anonymous 1912).

One of the courses that Fraser taught at Macdonald College was listed in the College Announcement as: "Course 6, Plant Diseases, a laboratory and field study of the common parasitic fungi of cultivated plants and methods of prevention and treatment; study of diseased tissues; cultural studies. A collection of 50 varieties of fungi is required of each student."

During his first year in Québec, Fraser demonstrated his ability as a naturalist by delivering a paper on the economic importance of land birds, to the Québec Society for the Protection of Plants (Fraser 1912b). In each of the following three years he addressed the members of that Society on some aspects of plant diseases. It was on diseases of forest and shade trees, with emphasis on the rusts, in 1913; storage rots of potatoes and other vegetables, in 1914; and the cereal rusts, in 1915. He was elected Director of the Society in 1916 and retained that position for three years.

Fraser spent three months, in the summer of 1915, in Nova Scotia assisting the Provincial Entomologist, W.H. Brittain, with his field work on plant disease problems for the Nova Scotia Department of Agriculture (Anonymous 1916). That was also the year in which he was promoted to the academic rank of Assistant Professor, and his major course at Macdonald College became "Plant Diseases and Fungi.» Fraser's teaching of that course inspired Margaret Newton, one of his students, to devote her life to studies on the rust fungi. While Margaret was still an undergraduate student, she and Fraser became the first Canadians to learn that grain rust fungi occur in physiologic races (Estey 1987).

Because of the devastating losses from grain rusts sustained by wheat growers on the Prairies in the summer of 1916, the Dominion Botanist, Hans Güssow (18791961), sent a questionnaire to farmers in all three Prairie provinces for information 
about the extent of the damage and where it first occurred. In February 1917, Fraser was hired, on a part-time basis, to analyze the replies, and on the recommendation of Güssow, he was appointed Officer in Charge of Grain Disease Investigations (Johnson 1961). During that year he displayed his versatility as a plant pathologist by publishing a paper on the overwintering of the apple-scab fungus (Fraser 1917).

Fraser made a personal survey of the grain disease situation in the Prairie provinces during the summers of 1917 and 1918, from temporary laboratories set up at Brandon and Indian Head. His official title, while doing that work, was Assistant in Charge of the Dominion Field Laboratory, Indian Head. At that time, the heads of all field laboratories of plant pathology in Canada were considered to be the Dominion Botanist's assistants.

Fraser was well liked by his students but his shyness was so apparent to them that on one occasion they placed bets on whether he would publicly kiss his wife goodbye at the train station prior to his leaving for one of those trips to Western Canada. He did not kiss her. (Personal communication with Dr. Dorothy Swales, a former student.)

\section{Professional life in Saskatchewan}

In 1919 Fraser resigned from his position at Macdonald College to become Assistant in Charge of a new Plant Pathology Field Laboratory on the campus of the University of Saskatchewan, in Saskatoon. He had not been there very long before Dr. W.P. Thompson, Professor of Biology in the University, arranged for him to do some teaching in his department, on a part-time basis from January through March. In Thompson's report to the acting President of the University, dated 27 March 1920, he commented, "Through the addition of Prof. Fraser to the staff it was possible for the first time to give adequate instruction in all the botanical work of the department. Prof. Fraser gives the class on Systematic Botany and Plant Pathology (Biology 6), he also directed the work of several special students." Fraser's course in plant pathology was listed in the University Calendar as "Fungi and Plant Diseases," and he is considered to have been the university's first plant pathologist.
Fraser realized that certain fundamental information about cereal rust diseases had to be determined before much progress could be made in controlling them. Thus he gave early attention to conditions that influence the spread and development of the rust fungi: their epidemiology. $\mathrm{He}$ studied various aspects of that problem from the time he made his first survey in 1917, until 1925. During the course of those studies much attention was given to the question of whether or not the rust fungus could survive the Canadian winter on grain stubble, straw and grasses, and then infect the succeeding crop of grain. Each spring for several years Fraser collected rust spores from dead grass and straw and learned that a few of them could infect seedlings of grain. He also played a leading role in the campaign to locate and destroy barberry (Berberis spp.) and buckthorn (Rhamnus spp.) bushes, the alternate hosts of grain rust fungi (Fraser 1923).

Those early projects were supplemented by studies on varietal resistance to rust disease and the prevalence of physiological races of Puccinia graminis tritici Eriks. \& E. Henn., the incitant of wheat stem rust. In these latter studies, he and Margaret Newton were Canadian pioneers. By 1924 they had shown that at least 17 races were present in Canada. To test varietal resistance of wheat (Triticum aestivum L.) to rust, and to make the pathologically different races or strains easier to collect, Fraser established «Uniform Rust Nurseries" at various places in the Prairie provinces (Johnson 1961).

Most of Fraser's research in Saskatchewan was centered around rust of wheat, but he also devoted his attention to other rusts. For example, he and G.A. Ledingham studied sedge rust, Puccinia caricis-shepherdiaeJ.J. Davis, (Fraser and Ledingham 1929) and the crown rust of oats, Puccinia coronata Corda (Fraser and Ledingham 1933).

Although preeminently a rust specialist, Fraser studied other diseases, especially those of the cereals and wild grasses. He initiated research on the smut fungi in Western Canada in 1918 when he studied the biology and control of Ustilago bullata Berk. on western rye grass, Agropyron tenerum Vasey (Fraser 1920). His 
experiments on the control of cereal smut diseases by seed treatment were begun in 1922 , and in the following year he cooperated with P.M. Simmonds in studies on the use of various substances for smut control (Fraser and Simmonds 1923). Fraser was the first to discover onion smut, Urocystis cepulae Frost, in Manitoba (Bisby and Conners 1928), and he was the first to report Polyspora lini Laff., on flax, Linum usitatissimum L., in Saskatchewan (Vanterpool 1947).

Fraser began to study the root diseases of wheat in 1921 when he reported that root rot, apparently incited by the fungus Helminthosporium sativum Pam., King, \& Bakke., was common in some areas of Saskatchewan. He, with his assistant, D.L. Bailey, described browning root rot, a diseased condition of the early growth stage of wheat (Simmonds 1939). In 1923, Fraser made the first Canadian discovery of Ophiobolus cariceti (B. \& Br.) Sacc., later named $O$. graminis (Sacc.) Sacc., the fungus that incites the take-all disease of wheat, on the roots of Triticum aestivum in northern Saskatchewan (Fraser 1924).

By 1924 Fraser was widely acknowledged as the preeminent Canadian authority on grain rusts. Evidence for this lies in the fact that he is the one who was asked to review the status of the cereal rust situation in Canada for the members of what became known as the Second Winnipeg Rust Conference; a conference of rust specialists convened by the National Research Council of Canada in cooperation with the Dominion Department of Agriculture in September 1925 (Anonymous 1925).

Fraser's dual employment with the Dominion Department of Agriculture and the University continued until 1925 when he resigned from the former and became a full-time Professor of Biology in the University. His areas of teaching expanded but were largely confined to Taxonomic Botany, Diseases of Plants, and Mycology. He continued to teach those courses, with variations, until he retired in 1937, at which time the University made him Emeritus Professor of Biology.

In recognition of his contributions to the solution of the cereal rust problem, and of his outstanding work on the native flora of Saskatchewan, the University of Saskatchewan bestowed on him an honorary LL.D. in 1937. That was a well deserved honor because Fraser had laid the foundation for plant disease work in that region, and for Canadian research on the cereal rusts (Vanterpool 1944).

For a short time prior to his retirement, Fraser was assisted in his botanical work by Dr. R.C. Russell who, at that time, was an employee of the Dominion Department of Agriculture. In 1937 they jointly compiled a list of the flowering plants, ferns and fern allies of Saskatchewan (Fraser and Russell 1937), to which Fraser made additions the following year. Fraser collected a wide range of plants and established an herbarium of Prairie flora. As a token of its appreciation for that endeavor, the University designated the collection as "The W.P. Fraser Herbarium."

Fraser's habitual reticence masked a sense of humor that sometimes contrasted sharply with his shyness, thus making it more memorable and entertaining. One of his colleagues at the University of Saskatchewan recalled the time Fraser took students on a plant disease survey and one student found an area in a farmer's field that had a high concentration of diseased plants. The student, on his first such survey and anxious to do everything just right, asked how he could describe the location of the diseased plants for future reference. Fraser suggested that it was about twenty feet west of a certain cow, and that the student should describe the cow well enough to recognize her the next time they came there (Taft 1984).

\section{Contributions and influence}

While still teaching, Fraser made a significant contribution to "The fungi of Manitoba and Saskatchewan;" a book that was sponsored by the National Research Council of Canada and published in 1938 (Bisby et al. 1938).

Fraser's collection of rust fungi and their host plants in his herbarium facilitated the work of I.L. Conners who made use of them to complete his survey of the plant rusts in 1925. That was a joint venture with Fraser (Conners 1972), who added to the list in 1931 (Fraser 1931). Thus, by the time the Dominion Rust Laboratory 
was established in Winnipeg, Fraser, together with Conners, had identified and listed most of the rusts of the Prairies.

It is impossible to judge just how much Fraser influenced the work in that new Rust Laboratory but it must have been substantial, because many of the early research staff there, including D.L. Bailey, I.L. Conners, J.H. Craigie, T. Johnson, Margaret Newton, and J.E. Machacek, were either his former students or research associates.

Fraser was never a self aggrandizing person, nevertheless his knowledge of plant pathology, especially the diseases of grasses, was widely recognized. $\mathrm{He}$ served for several years as a member of the Associate Committee on Field Crop Diseases of the National Research Council of Canada and the Dominion Department of Agriculture. He was elected President of the Canadian Division of the American Phytopathological Society, 1922-23, and thus became the Canadian Representative on the Council of that Society. He was a charter member of both the Canadian Phytopathological Society and the Canadian Society of Technical Agriculturists (the forerunner of the Agricultural Institute of Canada), and an elected Fellow of the American Association for the Advancement of Science. He was elected VicePresident 1929-1931 and President 19311933, of the Canadian Phytopathological Society, which made him an Honorary Member (Craigie 1944).

With the death of William Pollock Fraser on 23 November 1943, Canadian botanists, especially the mycologists and plant pathologists among them, lost one of their most distinguished native sons.

\section{ACKNOWLEDGEMENTS}

The author is indebted to Dr. Charles A. Armour, University Archivist, for providing photocopies of Dalhousie University senate minutes pertaining to Fraser's degrees, and to Lloyd G. White of Pictou, N.S., for copies of newspaper clippings, birth and marriage records, etc. The photograph of Fraser is by courtesy of University of Saskatchewan Archives.

\section{REFERENCES}

Anonymous. 1912. Pictou Advocate, July 20 1912. p. 12

Anonymous. 1916. Annual Report Secretary of Agriculture, Nova Scotia, for 1915. p. 30.

Anonymous. 1925. National Research Council Report for 1924-25. p. 19-20.

Arthur, J.C. 1910. Cultures of Urediniae in 1909. Mycology 2: 213-240.

Bisby, G.R., and I.L. Conners. 1928. Plant diseases new to Manitoba. Sci. Agric. 8: 456458.

Bisby, G.R., A.H.R. Buller, J. Dearness, W.P. Fraser, and R.C. Russell. 1938. The fungi of Manitoba and Saskatchewan. 189 pp.

Conners, I.L. 1972. Plant pathology in Canada. p. 16.

Craigie, J.H. 1927. Discovery of the function of the pycnia of the rust fungi. Nature 120: 765-767.

Craigie, J.H. 1944. William Pollock Fraser 18671943. Can. Field Nat. 58: 1-3.

Estey, R.H. 1987. Margaret Newton: Distinguished Canadian scientist and first woman member of the Québec Society for the Protection of Plants. Phytoprotection 68: 79-85.

Fraser, W.P. 1912a. Cultures of some heteroecious rusts. Mycologia 4: 175-193.

Fraser, W.P. 1912b. The economic importance of land birds. Annu. Rep. Qué. Soc. Prot. Plants 4: 44-55.

Fraser, W.P. 1913. The rusts of Nova Scotia. Trans. N.S. Inst. Sci. 12: 313-445.

Fraser, W.P. 1917. Over-wintering of the applescab fungus. Science 46: 280-282.

Fraser, W.P. 1920. A smut of western rye grass. Phytopathology 10: 316 (Abstract).

Fraser, W.P. 1923. Report of the field laboratory of plant pathology at Saskatoon, in cooperation with the University of Saskatchewan, and the field laboratory at: Indian Head for 1922. Page 46 In Report of the Dominion Botanist for 1922. See also Fraser's reports each year from 1919 to 1925

Fraser, W.P. 1924. "Take-all" of wheat in western Canada. Phytopathology 14: 347 (Abstract).

Fraser, W.P. 1931. Additions to the Uredinales of the prairie provinces of Canada. Trans. R. Soc. Can. Ser. 3 25: 85-92.

Fraser, W.P., and G.A. Ledingham. 1929. Studies on the sedge rust, Puccinia caricis shepherdiae. Mycologia 21: 86-89.

Fraser, W.P., and G.A. Ledingham. 1933. Studies of the crown rust, Puccinia coronata Corda. Sci. Agric. 13: 313-323. 
Fraser, W.P., and R.C. Russell. 1937. List of the flowering plants, ferns and fern allies in Saskatchewan. Mimeographed. $46 \mathrm{pp}$.

Fraser, W.P., and P.M. Simmonds. 1923. Cooperative experiments with copper carbonate dust and other substances for smut control. Sci. Agric. 3: 297-302.

Johnson, T. 1961. Rust research in Canada and related plant-disease investigations. Can. Dep. Agric. Publ. 1098. 69 pp.

MacKay, A. H. 1908. Fungi of Nova Scotia: First supplementary list. Trans. N.S. Inst. Sci. 12: 119-138.

Simmonds, P.M. 1939. A review of the investigations conducted in Western Canada on root diseases of cereals. Sci. Agric. 19: 565582.

Taft, M. 1984. Inside these greystone walls: An anecdotal history of the University of Saskatchewan. University of Saskatchewan Press, Saskatoon. $230 \mathrm{pp}$.

Vanterpool, T.C. 1944. William Pollock Fraser, 1867-1943. Mycologia 36: 313-317.

Vanterpool, T.C. 1947. Flax diseases in Saskatchewan. Annu. Rep. Dep. Agric. Sask. $207 \mathrm{pp}$. 